\title{
Eulogy to Professor John L. Fahey: My Teacher, Collaborator, and Professional Counselor
}

\author{
Benjamin Bonavida \\ Department of Microbiology, Immunology, \& Molecular Genetics, University of California at Los Angeles, Los Angeles, \\ CA 90095; E-mail: bbonavida@mednet.ucla.edu
}

My family and I were indeed very sad to learn of the early departure of Professor John L. Fahey, an exemplary academic scientist and administrator who contributed significantly to the biological sciences, unraveling many underlying mechanisms of several diseases, including cancer and HIV. His contributions have substantially improved human health worldwide.

I was fortunate to meet John for the first time at a 1970 immunology conference in Washington D.C. He had been recruited from the National Institutes of Health (NIH) to the University of California, Los Angeles (UCLA) to become the chair of the then department of microbiology and immunology at the School of Medicine. I was a postdoctoral fellow at the Weizmann Institute of Sciences, Rehovot, Israel, beginning in 1969 after receiving my Ph.D. degree at UCLA under the preceptorship of the late professor Eli Sercarz. John was recruiting new faculty at UCLA, and he requested an interview with me in Washington. During the interview, I was impressed by his vision, charisma, and knowledge and the new strategic program that he had developed for UCLA. Shortly after my interview, I received a formal letter offering me the position of assistant professor under his chairmanship. I accepted the offer and returned to Los Angeles, beginning my career in the fall of 1971.

Being a new faculty member, John took me under his wing and helped me to develop my research laboratory, prepare NIH research grants, and provide me with the initial financial support for my research, including research technicians and postdoctoral fellows. Along with other newly appointed faculty, fellows, and graduate students, he organized a weekly group meeting for a multidisciplinary program in immunobiology under the sponsorship of an NIH Program Project that he initiated and ran successfully for many years. With his help, I introduced a new niche of research in cell-mediated immunity and cytotoxicity in the fields of both allotransplantation and cancer. My laboratory continued to grow and be funded by the NIH, and our findings were published in highly refereed journals, initially in collaboration with John. Several of those joint publications are listed below.* With John's support and help, I was promoted to a tenured position as associate professor and subsequently a full professor.

\footnotetext{
*Zighelboim J, Bonavida B, Fahey JL. Evidence for several cell populations active in antibody dependent cellular cytotoxicity. J Immunol. 1973;111:1737.

Zighelboim J, Bonavida B, Rao VS, Fahey JL. Blocking activity induced by solubilized allantigens. J Immunol. 1974;112:433. Zighelboim J, Bonavida B, Fahey JL. Antibody-mediated in vivo suppression of EL4 leukemia in a syngeneic host. J Natl Cancer Inst. 1974;52:879.

Zighelboim J, Bonavida B, Fahey JL. Heterogeneous populations of cytotoxic cells in the peritoneal cavity of BALB/c mice immunized with allogeneic EL4 leukemia cells. Cell Immunol. 1974;12:280.

Rao VS, Bonavida B, Zighelboim J, Fahey JL. Preferential induction of serum blocking activity and enhancement of skin allograft by soluble alloantigen. Transplantation. 1974; 17:568.

Kedar E, de Landazuri OM, Bonavida B, Fahey JL. Cellular immunoabsorbents: An improved technique for specific depletion of cytotoxic (T) lymphoid cells. J Immunol Meth. 1974;5:97. Zighelboim J, Gale RP, Chiu A, Bonavida B, Ossorio RC, Fahey JL. Antibody dependent cellular cytotoxicity: Cytotoxicity mediated by non-T lymphocytes. Clin Immunol Immunopath. 1974;3:193.
} 
During the early years, John also successfully competed for an NIH immunology training grant supported postdoctoral fellows and Ph.D. graduate students. He was the principal investigator (PI) for many years, and subsequently asked me to take over as PI, a post that I held for many years. The program is now coordinated by Drs. Doug Smoot, Mike Teitel, and Steven Dubinett.

Over the years, I was close to John and regarded him as both a leader and father figure; he sustained my research career without hesitation. Clearly, his early departure has left me with a void. Without his care and compassion, I would not be where I am today. He has taught me the intricate tools of the art of scientific pursuit, excellence in the training of postdoctoral fellows and graduate students, and formal teaching. John and his family were friendly with my family, relationships that were maintained throughout the years.

Following John's departure, I am dedicating this special issue of the journal Forum of Immunological Diseases and Therapeutics, for which I serve as editor, to honor his memory. Both Oto Martinez-Maza and Christel Uittenbogaart have kindly agreed to edit the present issue, and I am indebted to both of them. Although John has departed physically, his spirit and love will live forever. 